\title{
Pengaruh Umur Perusahaan, Profitabilitas dan Pertumbuhan Penjualan Terhadap Tax Avoidance
}

\author{
Tongam Sinambela \\ Universitas Mpu Tantular - Jakarta \\ Lisa Nur'aini \\ Universitas Mpu Tantular - Jakarta \\ Email: tongamsinambela@gmail.com
}

\begin{abstract}
Abstrak
This study aims to obtain empirical evidence about the effect of Firm Age, Profitability (Return on Assets), and Sales Growth (Sales Growth) on tax avoidance. This study is a quantitative study using secondary data in the form of financial reports and annual reports of food and beverage sub-sector manufacturing companies listed on the Indonesia Stock Exchange from 2015 to 2019. The sample selection used the purpose sampling method. The data analysis technique uses multiple regression analysis with SPSS 20. The results of this study are that the age of the company has a positive and significant effect on tax avoidance. Variable return on assets has a positive effect on tax avoidance. Sales growth variable has no effect on tax avoidance. This is because high sales growth does not necessarily affect the profit generated because each period also produces a different cost of goods sold.
\end{abstract}

Keywords: Tax Avoidance, Company Age, Profitabilitas, Sales Growth

\section{Pendahuluan}

Fenomena mengenai pemungutan pajak menjadi fenomena penting yang menjadi fokus pemerintah dan harus dikelola dengan baik, pelaksanaan pemungutan pajak oleh pemerintah, tidaklah selalu mendapat sambutan baik dari perusahaan. Perusahaan berusaha untuk membayar pajak serendah mungkin karena pajak akan mengurangi pendapatan atau laba bersih, sedangkan bagi pemerintah menginginkan pajak setinggi mungkin guna untuk membiayai penyelenggaraan pemerintahan (Oktamawati, 2017).

Aktivitas penghindaran pajak (tax avoidance) dapat dipengaruhi oleh beberapa faktorfaktor diantaranya adalah Kinerja keuangan dan corporate governance (Kurniasih \& Ratna Sari, 2013). Return on Assets (ROA) merupakan satu indikator dari kinerja keuangan yang mencerminkan performa keuangan perusahaan, semakin tinggi nilai ROA, maka akan semakin bagus performa perusahaan tersebut. ROA berkaitan dengan laba bersih perusahaan dan pengenaan pajak penghasilan untuk Wajib Pajak Badan.

Tahun 2014, PT Toyota Manufacturing Indonesia telah melakukan praktik penghindaran pajak dengan mengekspor ribuan mobil dengan nilai ekspor lebih kecil dari biaya penjualan. Sedangkan, produk yang sama dijual di Indonesia dengan harga yang berbeda. Untuk melakukan ekspor Toyota memiliki kebijakan dengan unit bisnisnya di Singapura yaitu Toyota Motor Asia Pacific Pte., Ltd karena Singapura memiliki tarif pajak korporasi terendah di Asia Tenggara. Untuk menurunkan jumlah pajak yang harus dibayar di Indonesia, PT Toyota melakukan transfer pricing melebihi batas wajar usaha. Direktorat Jenderal Pajak Kementerian Keuangan sudah mencurigai TMMIN memanfaatkan transaksi antar perusahaan terafiliasi di dalam dan di luar negeri untuk menghindari pembayaran pajak dengan transfer pricing. 
Tax avoidance (penghindaran pajak) adalah upaya penghindaran pajak yang dilakukan secara legal dan aman bagi wajib pajak karena dilakukan dengan cara- cara yang tidak melanggar dan tidak bertentangan dengan ketentuan perpajakan, di mana metode dan teknik yang digunakan cenderung memanfaatkan kelemahan- kelemahan yang terdapat dalam ketentuan perpajakan. Sedangkan tax evasion merupakan perilaku ilegal karena melanggar undang- undang atau peraturan yang berlaku. Namun dalam penerapannya perilaku tersebut dianggap etis atau wajar untuk dilakukan pemimpin yaitu seperti penyalahgunaan dana pajak untuk kepentingan pribadi ataupun kelompok, tidak tersistematisnya sistem perpajakan dan adanya peraturan perpajakan yang dianggap hanya menguntungkan satu pihak dan merugikan pihak lainnya (Indriyani et al., 2016).

Penelitian-penelitian terdahulu yang menguji faktor yang mempengaruhi perusahaan untuk melakukan penghindaran pajak (tax avoidance). Faktor pertama adalah umur perusahaan, umur perusahaan yaitu seberapa lama perusahaan tersebut berdiri dan dapat bertahan di BEI. Umur perusahaan menunjukkan seberapa lama perusahaan untuk tetap eksis dan mampu bersaing di dalam dunia usaha. Umur perusahaan dalam penelitian ini menggunakan umur perusahaan dari tanggal perusahaan terdaftar di BEI (Rosa Dewinta \& Ery Setiawan, 2016).

Faktor kedua adalah profitabilitas merupakan salah satu pengukuran bagi kinerja suatu perusahaan. Profitabilitas suatu perusahaan menggambarkan kemampuan suatu perusahaan dalam menghasilkan laba selama periode tertentu pada tingkat penjualan, asset dan modal saham tertentu. Profitabilitas menunjukan kinerja keuangan perusahaan dalam menghasilkan laba dari pengelolaan aktiva yang di kenal dengan Return on Asset (ROA), semakin tinggi ROA maka semakin besar laba yang diperoleh perusahaan dan sebaliknya, sehingga semakin tinggi tingkat ROA maka laba perusahaan semakin tinggi sehingga pajak yang di bebankan perusahaan akan semakin tinggi. Hal ini membuat perusahaan untuk melakukan tindakan penghindaran pajak (Hidayat, 2018).

Faktor ketiga adalah pertumbuhan penjualan (sales growth) merupakan sebagai tolak ukur berkembangnya suatu perusahaan yang dapat dilihat dari nilai keuntungan dari laporan keuangan yang diperoleh tiap tahun, dengan demikian dapat dikaitkan sebagai alat untuk perkembangan perusahaan. Pertumbuhan penjualan dapat menunjukkan kemampuan perusahaan dalam meningkatkan tingkat penjualannya dari waktu ke waktu. Tingkat pertumbuhan penjualan yang tinggi mencerminkan keberhasilan strategi penjualan dan pemasaran produk dari suatu perusahaan.

Berdasarkan uraian latar belakang dan fenomena penghindaran pajak yang terjadi beberapa tahun belakangan maka penulis terdorong untuk melakukan pengujian terhadap penghindaran pajak, dengan mengembangkan variabel dari penelitian-penelitian terdahulu.

\section{Landasan Teori dan Pengembangan Hipotesis}

\section{Teori Kepatuhan (Compliance Theory)}

Menurut (Murphy \& Tyler, 2008) terdapat dua perspektif dasar dalam literatur sosiologi mengenai kepatuhan pada hukum, yang disebut instrumental dan normatif. Perspektif instrumental mengasumsikan individu secara utuh didorong oleh kepentingan pribadi dan tanggapan terhadap perubahan-perubahan dalam tangible, insentif, dan penalti yang berhubungan dengan perilaku. Perspektif normatif berhubungan dengan apa yang orang anggap sebagai moral dan berlawanan dengan kepentingan pribadi mereka. Dalam hal penyampaian laporan keuangan ke publik, perspektif instrumental menggambarkan bahwa insentif yang diperoleh perusahaan bila menyampaikan laporan keuangannya dengan tepat waktu yaitu respon baik publik terhadap perusaaan itu sendiri, dan sebaliknya. Sedangkan 
untuk perspektif yang kedua, seorang individu cenderung untuk mematuhi ketentuan dalam hal ini ketepatan waktu pelaporan keuangan karena dianggap sebagai suatu keharusan (normative commitment through morality) dan karena otoritas penyusun ketentuan tersebut untuk mendikte perilaku untuk melaporkan keuangannya tepat pada waktu yang telah ditentukan (normative commitment through legitimacy) dalam hal ini adalah Bapepam. Teori kepatuhan dapat mendorong seseorang untuk lebih mematuhi peraturan yang berlaku, sama halnya dengan perusahaan yang berusaha untuk menyampaikan laporan keuangan secara tepat waktu karena selain merupakan suatu kewajiban perusahaan untuk menyampaikan laporan keuangan tepat waktu, juga akan sangat bermanfaat bagi para pengguna laporan keuangan.

\section{Teori Keagenan (Agency Theory).}

Penelitian ini menggunakan teori dasar yaitu teori keagenan atau agency theory. Agency theory adalah teori yang menjelaskan hubungan antara agen sebagai pihak yang mengelola perusahaan dan prinsipal sebagai pihak pemilik, keduanya terikat dalam sebuah kontrak. Pemilik atau prinsipal adalah pihak yang melakukan evaluasi terhadap informasi dan agen adalah sebagai pihak yang menjalankan kegiatan manajemen dan mengambil keputusan. (Jensen \& Meckling, 1976) menyatakan bahwa teori keagenan merupakan teori ketidaksamaan kepentingan antara prinsipal dan agen. Teori agensi mendasarkan hubungan kontrak antara pemegang saham atau pemilik serta manajemen atau manajer. Menurut teori ini, hubungan antara pemilik dan manajer pada hakikatnya sukar tercipta karena adanya kepentingan yang saling bertentangan.

Dalam teori keagenan (agency theory), hubungan agensi muncul ketika satu orang atau lebih (prinsipal) memperkerjakan orang lain (agen) untuk memberikan suatu jasa dan kemudian mendelegasikan wewenang pengambilan keputusan kepada agen tersebut. Hubungan antara prinsipal dan agen dapat mengarah pada kondisi ketidak seimbangan informasi (asymmetrical information) karena agen berada pada posisi yang memiliki informasi yang lebih banyak tentang perusahaan dibandingkan dengan prinsipal. Dengan asumsi bahwa individu-individu bertindak untuk memaksimalkan kepentingan diri sendiri, maka dengan informasi asimetri yang dimilikinya akan mendorong agen untuk menyembunyikan beberapa informasi yang tidak diketahui prinsipal. Dalam kondisi yang asimetris tersebut, agen dapat mempengaruhi angkaangka akuntansi yang disajikan dalam laporan keuangan dengan cara melakukan manajemen laba. Akibat adanya informasi yang tidak seimbang ini dapat menimbulkan 2 (dua) permasalahan yang menyebabkan adanya kesulitan prinsipal untuk memonitor dan melakukan control terhadap tindakan-tindakan agen.

\section{Umur Perusahaan}

Umur perusahaan adalah lamanya sebuah perusahaan berdiri, berkembang dan bertahan. Umur perusahaan dihitung sejak perusahaan tersebut berdiri berdasarkan akta pendirian sampai penelitian dilakukan. Umur perusahaan menunjukkan seberapa lama perusahaan untuk tetap eksis dan mampu bersaing di dalam dunia usaha. Umur perusahaan dalam penelitian ini menggunakan umur perusahaan dari tanggal perusahaan terdaftar di Bursa Efek Indonesia (Widiayani et al., 2019).

Umur perusahaan juga dapat mempengaruhi adanya aktivitas tax avoidance. Hal ini disebabkan karena pada saat perusahaan sudah terdaftar di BEI dan go public, maka perusahaan harus mempublikasikan pelaporan keuangannya kepada masyarakat dan pemakai laporan keuangan agar informasi yang ada di dalamnya dapat segera digunakan oleh pihak-pihak yang membutuhkan. Perusahaan yang mengalami penuaan harus mengurangi biaya termasuk biaya pajaknya akibat pengalaman dan pembelajaran yang dimiliki oleh perusahaan serta pengaruh perusahaan lain baik dalam industri yang sama maupun berbeda. Perusahaan dengan jangka 
waktu operasional lebih lama juga akan membuat perusahaan lebih ahli dalam mengatur pengelolaan pajaknya yang berdasarkan pengalaman-pengalaman sebelumnya. Sumber daya manusia yang ahli dalam perpajakan diperlukan untuk menekan beban pajak perusahaan sehingga pengelolaan pajak yang dilakukan oleh perusahaan dapat maksimal.

\section{Profitabilitas}

Rasio profitabilitas merupakan rasio yang digunakan untuk mengukur kemampuan perusahaan dalam menghasilkan laba dari aktivitas bisnis. Rasio profitabilitas juga merupakan rasio yang menggambarkan kemampuan perusahaan dalam menghasilkan laba melalui semua kemampuan dan sumber daya yang dimilikinya, yaitu yang berasal dari kegiatan penjualan, penggunaan aset, kemampuan penggunaan modal. Rasio profitabilitas dapat digunakan sebagai alat untuk mengukur tingkat efektivitas kinerja manajemen. Kinerja yang baik akan ditunjukan lewat keberhasilan manajemen dalam menghasilkan laba yang maksimal bagi perusahaan (Hery, 2015). Semakin rendah atau kecilnya rasio ini semakin kurang baik, demikian sebaliknya, oleh karna itu rasio ini digunakan untuk mengukur efektifitas dan keseluruhan operasi perusahaan. Profitabilitas dapat di prosikan pada rasio Return on Asset (ROA) dimana membandingkan laba setelah pajak dengan total asset.

\section{Pertumbuhan Penjualan}

Perusahaan yang memiliki penjualan yang cenderung meningkat akan mendapatkan profit yang meningkat pula. Ketika profit yang di dapatkan perusahaan itu besar, beban pajak yang harus ditanggung oleh perusahaan juga besar pula. Oleh karena itu, perusahaan yang mendapatkan profit tinggi, cenderung berusaha mengurangi pajak yang harus dibayarkan dengan cara melakukan praktik tax avoidance.

Pertumbuhan penjualan (Sales Growth) merupakan sebagai tolak ukur berkembangnya suatu perusahaan yang dapat dilihat dari nilai keuntungan dari laporan keuangan yang diperoleh tiap tahun, dengan demikian dapat dikaitkan sebagai alat untuk perkembangan perusahaan. Pertumbuhan penjualan dapat menunjukkan kemampuan perusahaan dalam meningkatkan tingkat penjualannya dari waktu ke waktu.

Tingkat pertumbuhan penjualan yang tinggi mencerminkan keberhasilan strategi penjualan dan pemasaran produk dari suatu perusahaan. Pertumbuhan penjualan merupakan rasio antara penjualan tahun sekarang di kurangi penjualan tahun kemarin dan di bagi penjualan tahun kemarin.

\section{Penghindaran Pajak (Tax Avoidance)}

Secara ekonomis pajak merupakan unsur pengurang laba yang tersedia untuk dibagi atau di investasikan kembali oleh perusahaan. Dalam praktik bisnis umumnya pengusaha mengidentifikasikan pembayaran pajak sebagai beban, sehingga akan berusaha untuk meminimalkan beban tersebut untuk mengoptimalkan laba. Sebagai suatu beban, pajak menimbulkan pro dan kontrak. Pajak dimata negara merupakan sumber penerimaan untuk membiayai peyelenggaraan pemerintahan namun dalam implementasinya suatu negara akan menghadapi kendala terutama terkait dengan kemauan perusahaan untuk membayar pajak. Dalam hal ini akan muncul prilaku tax avoidance (legal) dan tax evasion (ilegal) dari perusahaan sebagai wujud dari keengganannya dalam membayar pajak yang dibebankan oleh negara kepadanya.

Penghindaran pajak (tax avoidance) adalah upaya penghindaran pajak yang dilakukan secara legal dan aman bagi wajib pajak tanpa bertentangan dengan ketentuan perpajakan yang berlaku (not contrary to the law) dimana metode dan teknik yang digunakan cenderung 
memanfaatkan kelemahan-kelemahan (grey area) yang terdapat dalam undang-undang dan peraturan perpajakan itu sendiri.

Tax avoidance adalah pengaturan untuk meminimumkan atau menghilangkan beban pajak dengan mempertimbangkan akibat pajak yang ditimbulkannya (Dinah \& Darsono, 2017). Variabel dependen dalam penelitian ini adalah Tax avoidance. Tax avoidance merupakan strategi pajak agresif yang dilakukan oleh perusahaan dalam langkah meminimalkan beban pajak, tanpa bertentangan dengan peraturan perundang-undangan perpajakan karena praktik yang berhubungan dengan Tax avoidance lebih memanfaatkan celah-celah dalam undangundang perpajakan tersebut yang akan mempengaruhi penerimaan negara sektor pajak.

\section{Pengembangan Hipotesis}

\section{Pengaruh Umur Perusahaan terhadap Penghindaran Pajak}

Seiring dengan berjalannya waktu, perusahaan akan menjadi tidak efisien (Loderer \& Waelchli, 2010). Perusahaan yang mengalami penuaan harus mengurangi biaya termasuk biaya pajaknya akibat pengalaman dan pembelajaran yang dimiliki oleh perusahaan serta pengaruh perusahaan lain baik dalam industri yang sama maupun berbeda. Perusahaan dengan jangka waktu operasional lebih lama juga akan membuat perusahaan lebih ahli dalam mengatur pengelolaan pajaknya yang berdasarkan pengalaman-pengalaman sebelumnya. Sumber daya manusia yang ahli dalam perpajakan diperlukan untuk menekan beban pajak perusahaan sehingga pengelolaan pajak yang dilakukan oleh perusahaan dapat maksimal. Secara logika, semakin lama jangka waktu operasional suatu perusahaan, semakin banyak pengalaman yang dimiliki oleh perusahaan tersebut dan sumber daya manusia yang dimiliki semakin ahli dalam mengatur dan mengelola beban pajaknya sehingga kecenderungan untuk melakukan tax avoidance semakin tinggi. Berdasarkan uraian tersebut, maka hipotesis dalam penelitian ini sebagai berikut.

$\boldsymbol{H}_{1}$ : Umur perusahaan berpengaruh positif terhadap tax avoidance.

\section{Pengaruh Profitabilitas terhadap Penghindaran pajak}

Profitabilitas menunjukan kinerja keuangan perusahaan dalam Return on asset (ROA), (Putriningsih et al., 2018) bahwa semakin tinggi return on asset maka semakin besar laba yang di diperoleh perusahaan dan sebaliknya, sehingga semakin tinggi tingkat ROA maka laba perusahaan semakin tinggi sehingga pajak yang di bebankan perusahaan akan semakin tinggi, sehingga perusahaan akan melakukan tindakan penghindaran pajak. Penelitian (Jusman \& Nosita, 2020) Menunjukkan bahwa Return on asset berpengaruh negative terhadap tax avoidance. Kemudian (Subagiastra et al., 2017) menunjukkan bahwa laba atas aset sebagai proxy dari profitabilitas berpengaruh positif terhadap penghindaran pajak. Hal ini menunjukkan bahwa semakin meningkatnya profitabilitas perusahaan maka semakin tinggi terjadinya praktik penghindaran pajak.

$\boldsymbol{H}_{2}:$ Return on assets (ROA) berpengaruh positif terhadap penghindaran pajak.

\section{Pengaruh Pertumbuhan Penjualan terhadap Penghindaran Pajak}

Semakin besar penjualan, maka semakin besar laba yang akan diperoleh perusahaan sehingga laba yang dibebankan oleh perusahaan akan semakin besar. Penelitian (Rosa Dewinta \& Ery Setiawan, 2016), (Oktamawati, 2019) menunjukkan bahwa pertumbuhan penjualan berpengaruh positif terhadap penghindaran pajak. Sedangkan (Hidayat, 2018) menjelaskan bahwa pertumbuhan penjualan berpengaruh negatif terhadap penghindaran pajak. Artinya semakin tinggi penjualan maka semakin besar juga potensi perusahaan untuk melakukan penghindaran pajak. 
$\boldsymbol{H}_{3}$ : Pertumbuhan penjualan berpengaruh positif terhadap penghindaran pajak.

\section{Metode Penelitian}

Studi ini merupakan riset kuantitatif. Data riset diperoleh dari laporan keuangan masingmasing perusahaan manufaktur sektor makanan dan minuman yang terdaftar di Bursa Efek Indonesia (BEI) tahun 2015-2019. Penelitian ini menggunakan Teknik nonprobability sample sesuai kriteria tertentu yang disebut purposive sampling (Blumberg et al., 2014). Sampel keseluruhan dalam penelitian ini adalah 65 sampel.

\section{Variabel Penelitian dan Definisi Operasional}

Variabel dependen yang digunakan dalam penelitian ini adalah Penghindaran pajak (Tax Avoidance). Penghindaran pajak diukur dengan menggunakan proksi Cash Effective Tax rate (CETR). Cash ETR yaitu, kas yang dikeluarkan untuk biaya pajak dibagi dengan laba sebelum pajak. Rumus untuk menghitung Cash ETR merujuk dari penelitian (Chen et al., 2010) sebagai berikut :

$$
\mathbf{C E T R}=\frac{\text { Pembayaran Pajak }}{\text { Laba Sebelum Pajak }}
$$

Variabel Independen adalah variabel yang menjadi sebab terjadinya atau mempengaruhi variabel dependen. Variabel independen dalam penelitian ini adalah Umur Perusahaan, Profitabilitas, dan Pertumbuhan Penjualan. Umur perusahaan dalam penelitian ini menggunakan dari tahun perusahaan itu terdaftar di Bursa Efek Indonesia.

Tabel 1. Operasional Variabel

\begin{tabular}{|c|c|c|c|}
\hline No & Variabel & Indikator & Skala \\
\hline 1. & Cash Effective Tax rate (Y) & $\begin{array}{c}\text { CET } \boldsymbol{R}= \\
\text { Pembayaran Pajak } \\
\text { Laba Sebelum Pajak }\end{array}$ & Rasio \\
\hline 2. & Umur Perusahaan $\left(\mathrm{X}_{1}\right)$ & $\begin{array}{c}\boldsymbol{U M U} \boldsymbol{\boldsymbol { R }}= \\
(\text { Thn Penelitan }- \text { Thn Pendirian Perusahaan })\end{array}$ & Rasio \\
\hline 3. & Return On Assets $\left(\mathrm{X}_{2}\right)$ & $\begin{array}{c}\text { ROA }= \\
\frac{\text { Laba Rugi Setelah Pajak }}{\text { Total Aset }} \text { X100\% }\end{array}$ & Rasio \\
\hline 4. & Pertumbuhan penjualan $\left(\mathrm{X}_{3}\right)$ & $\begin{array}{c}\text { Sales Growth }= \\
\frac{\text { Penjualan Akhir }- \text { Penjualan Awal }}{\text { Penjualan Awal }}\end{array}$ & Rasio \\
\hline
\end{tabular}

Sumber : Diolah oleh penulis, 2020

\section{Teknik Pengumpulan dan Analisis Data}

Metode dokumentasi merupakan metode yang dipakai dalam pengumpulan data studi ini. Metode dokumentasi berbentuk laporan keuangan dari masing-masing perusahan yang menjadi sampel peneltian. Sedangkan analisis data penelitian ini menggunakan teknik analisis regresi berganda dengan software SPSS 20. Analisis data pertama dengan pengujian asumsi klasik yang terdiri dari uji normalitas, uji autokorelasi, uji multikolinearitas, dan uji heterokedastisitas. Selanjutnya adalah uji analisis regresi berganda, uji simultan, uji parsial, dan uji koefisien determinasi (R2). 


\section{Pembahasan}

\section{Analisis Statistik Deskriptif}

Tabel 2. Statistik Deskriptif

Descriptive Statistics

\begin{tabular}{|l|r|r|r|r|r|}
\hline & $\mathrm{N}$ & $\begin{array}{c}\text { Minimu } \\
\mathrm{m}\end{array}$ & $\begin{array}{c}\text { Maximu } \\
\mathrm{m}\end{array}$ & Mean & $\begin{array}{c}\text { Std. } \\
\text { Deviation }\end{array}$ \\
\hline UMUR_PRSH & 65 & 18,00 & 88,00 & 41,3077 & 18,10725 \\
ROA & 65 &, 00 &, 61 &, 1260 &, 12457 \\
SALES & 65 &,- 70 & 1,19 &, 0783 &, 22005 \\
GROWTH & 65 &, 00 & 7,63 &, 4409 &, 96969 \\
TA & 65 & & & & \\
Valid N & & & & \\
(listwise) & & & & \\
\hline
\end{tabular}

Sumber: Output SPSS

Berdasarkan output SPSS di atas, maka variabel tax avoidance menunjukkan nilai minimum sebesar 0\% yang terjadi pada PT Tri Banyan Tirta Tbk di tahun 2018 dan nilai maksimum sebesar 763\% yang terjadi pada PT. Prashida Aneka Niaga, Tbk di tahun 2019. Dengan nilai rata-rata sebesar $44 \%$ Perusahaan manufaktur subsektor makanan dan minuman yang melakukan penghindaran pajak. Kemudian variabel umur perusahaan menunjukkan bahwa nilai minimum sebesar 18 yang terjadi pada PT. Tri Banyan Tirta, Tbk di tahun 2015 dan nilai maksimum sebesar 88 yang terjadi pada PT Multi Bintang Indonesia, Tbk di tahun 2019. Nilai rata-rata umur perusahaan $\log$ n 41,3 sehingga dapat dikategorikan dalam Perusahaan Besar. Sementara untuk variabel ROA menunjukkan nilai minimum sebesar $0 \%$ yang terjadi pada PT. Sekar Bumi Tbk di tahun 2019 dan nilai maksimum sebesar $61 \%$ yang terjadi pada PT. Indofood Sukses Makmur, Tbk di tahun 2019. Nilai rata-rata laba $12 \%$ untuk perusahaan manufaktur subsector makanan dan minuman. Sedangkan variabel pertumbuhan penjualan menunjukkan nilai minimum sebesar $-70 \%$ yang terjadi pada PT. Delta Djakarta, Tbk di tahun 2019 dan nilai maksimum sebesar 119\% yang terjadi pada PT. Sekar Laut, Tbk di tahun 2015. Nilai rata-rata 7\% Pertumbuhan Penjualan semakin menurun dari tahun ke tahun.

\section{Analisis Regresi Linier Berganda}

Tabel 2. Hasil Regresi Linier Berganda

Coefficients $^{\mathbf{a}}$

\begin{tabular}{|c|c|c|c|c|c|c|}
\hline \multirow{2}{*}{\multicolumn{2}{|c|}{ Model }} & \multicolumn{2}{|c|}{$\begin{array}{c}\text { Unstandardized } \\
\text { Coefficients }\end{array}$} & $\begin{array}{c}\text { Standardized } \\
\text { Coefficients }\end{array}$ & \multirow[t]{2}{*}{$\mathrm{t}$} & \multirow[t]{2}{*}{ Sig. } \\
\hline & & $\mathrm{B}$ & Std. Error & Beta & & \\
\hline \multirow{4}{*}{1} & (Constant) &, 407 &, 147 & & 2,768 & ,008 \\
\hline & UMUR_PRSH_LN & ,077 & ,025 &, 459 & 3,129 &, 003 \\
\hline & ROA_LN & $-1,066$ & ,220 &,- 711 & $-4,839$ & ,000 \\
\hline & $\begin{array}{l}\text { SALES } \\
\text { GROWTH LN }\end{array}$ &,- 055 &, 145 &,- 046 &,- 379 & ,707 \\
\hline
\end{tabular}

Sumber: Output SPSS 
Berdasarkan hasil analisis regresi berganda diatas dapat dijeleskan bahwa koefisien regresi variabel umur perusahaan bernilai positif sebesar 0,077 dengan nilai sifikansi sebesar 0,003 dimana nilainya lebih kecil daripada $\alpha=0,05$. Hal ini menunjukkan bahwa variabel umur perusahaan berpengaruh positif terhadap tax avoidance. Kemudian koefisien regresi variabel ROA bernilai negatif sebesar -1,066 dengan nilai signifikansi sebesar 0,000 dimana nilainya lebih kecil daripada $\alpha=0,05$. Hal ini menunjukkan variabel ROA berpengaruh positif terhadap variabel tax avoidance. Kemudian koefisien regresi pertumbuhan penjualan bernilai negatif sebesar $-0,055$ dengan nilai signifikansi sebesar 0,707 dimana nilai $\alpha=0,05$. Hal ini menunjukkan variabel pertumbuhan penjualan tidak berpengaruh positif terhadap variabel tax avoidance. Sedangkan berdasarkan hasil analisis regresi menghasilkan Adjusted R Square sebesar 0,29. Hal ini berarti bahwa tax avoidance dapat dijelaskan oleh variabel umur perusahaan, return on asset (ROA), dan pertumbuhan penjualan sebesar 29\%. Sedangkan sisanya $71 \%$ di jelaskan oleh variabel lain di luar model penelitian ini.

\section{Pengaruh Umur Perusahaan Terhadap Tax Avoidance}

Variabel Umur Perusahaan berpengaruh positif terhadap Tax Avoidance. Penelitian ini konsisten dengan penelitian (Rosa Dewinta \& Ery Setiawan, 2016), (Widiayani et al., 2019), (Triyanti et al., 2020) yang menunjukan berpengaruh positif umur perusahaan terhadap tax avoidance. Hal ini menunjukkan semakin lama jangka waktu operasional suatu perusahaan, semakin banyak pengalaman yang dimiliki oleh perusahaan tersebut dan sumber daya manusia yang dimiliki semakin ahli dalam mengatur dan mengelola beban pajaknya sehingga kecenderungan untuk melakukan tax avoidance semakin tinggi.

\section{Pengaruh Profitabilitas (ROA) Terhadap Tax Avoidance}

Variabel ROA berpengaruh positif terhadap variabel tax avoidance. ROA menunjukkan laba bersih suatu perusahaan karena semakin tinggi nilai dari ROA, maka semakin tinggi juga laba bersih perusahaan. Hasil penelitian ini konsisten dengan penelitian (Kurniasih \& Ratna Sari, 2013). Sedangkan penelitian (Sugiyarti, 2017) profitabilitas berpengaruh negarif terhadap penghindaran pajak. Kemudian (Subagiastra et al., 2017) menunjukkan bahwa laba atas aset sebagai proxy dari profitabilitas berpengaruh positif terhadap penghindaran pajak. Hal ini menunjukkan bahwa semakin meningkatnya profitabilitas perusahaan maka semakin tinggi terjadinya praktik penghindaran pajak.

\section{Pengaruh Pertumbuhan Penjualan Terhadap Tax Avoidance}

Variabel pertumbuhan penjualan tidak berpengaruh positif terhadap variabel Tax Avoidance. Pertumbuhan Penjualan adalah Rasio yang digunakan untuk mengukur pertumbuhan penjualan dari periode ke periode berikutnya. Hasil penelitian ini berbeda dengan hasil penelitian (Hidayat, 2018) yang menunjukan terdapat pengaruh positif Pertumbuhan Penjualan terhadap Tax Avoidance. Hal ini kemungkinan terjadi dikarenakan semakin tinggi pertumbuhan penjualan, maka semakin berkurang aktivitas tax avoidance suatu perusahaan yang disebabkan karena perusahaan dengan tingkat penjualan yang relatif besar akan memberikan peluang untuk memperoleh laba yang besar dan mampu untuk melakukan pembayaran pajak.

\section{Pengaruh Umur Perusahaan, Return on Asset (ROA), dan Pertumbuhan Penjualan Terhadap Tax Avoidance}

Berdasarkan hasil analisis diketahui bahwa analisis regresi menghasilkan Adjusted $R$ Square sebesar 0,29. Hal ini berarti bahwa Tax Avoidance dapat dijelaskan oleh variabel Umur 
Perusahaan, Return on Asset (ROA), dan pertumbuhan penjualan sebesar 29\%. sedangkan sisanya $71 \%$ di jelaskan oleh variabel lain di luar model penelitian ini. Hasil tersebut juga menunjukkan bahwa nilai signifikansi sebesar 0,000 yang lebih kecil dari 0,05 yang berarti umur perusahaan, return on asset (ROA), dan pertumbuhan penjualan secara simultan berpengaruh terhadap tax avoidance hal ini sesuai dengan penelitian (Sinambela \& Naibaho, 2019) yang menyatakan bahwa variabel ROA berpengaruh secara simultan terhadap tax avoidance.

\section{Kesimpulan}

Berdasarkan hasil pengujian yang dilakukan terhadap perusahaan sampel, maka diperoleh kesimpulan sebagai berikut: 1) Hasil penelitian menunjukkan bahwa umur perusahaan berpengaruh signifikan terhadap penghindaran pajak. Hal ini disebabkan karena semakin lama jangka waktu operasional perusahaan, semakin tinggi pula aktivitas tax avoidance perusahaan yang disebabkan karena perusahaan dengan jangka waktu operasional yang relatif lebih lama akan lebih terampil dan lebih berpengalaman dalam pengelolaan manajemen keuangan terkait dengan urusan pajak. 2) Hasil penelitian menunjukkan bahwa variabel profitabilitas berpengaruh signifikan terhadap penghindaran pajak. Semakin tinggi profitabilitas, semakin rendah penghindaran pajak yang akan dilakukan perusahaan. 3) Hasil penelitian menunjukkan bahwa Sales Growthberpengaruh negative terhadap penghindaran pajak. Jika pertumbuhan penjualan naik, maka akan menurunkan penghindaraan pajak. Pertumbuhan Penjualan berpengaruh negative terhadap penghindaran pajak, dimana perusahaan yang sedang tumbuh penjualannya serta dilakukan dengan efisiensi maka akan mempereroleh keuntungan yang besar.

Saran bagi penelitian selanjutnya yaitu agar menggunakan sampel dari perusahaan selain perusahaan sub sektor makanan dan minuman bisa menggunakan perusahaan sektor usaha lainnya atau perusahan jasa keuangan lainnya sehingga hasil penelitian dapat meneliti lebih jauh pengaruh variabel-variabel umur perusahaan, profitabilitas (Return on Assets) dan Pertumbuhan Penjualan (Sales Growth) terhadap penghindaran pajak pada sektor usaha lainnya.

\section{Daftar Pustaka}

Blumberg, B., Cooper, D., \& Schindler, P. (2014). EBOOK: Business Research Methods. McGraw Hill.

Chen, S., Chen, X., Cheng, Q., \& Shevlin, T. (2010). Are family firms more tax aggressive than non-family firms? Journal of Financial Economics, 95(1), 41-61.

Dinah, A. F., \& Darsono, D. (2017). Pengaruh Tata Kelola Perusahaan, Profitabilitas, dan Penghindaran Pajak terhadap Nilai Perusahaan. Diponegoro Journal of Accounting, 6(3), $1-15$.

Hery. (2015). Analisis Laporan Keuangan. PT Grasindo.

Hidayat, W. W. (2018). Pengaruh Profitabilitas, Leverage Dan Pertumbuhan Penjualan Terhadap Penghindaran Pajak. Jurnal Riset Manajemen Dan Bisnis (JRMB) Fakultas Ekonomi UNIAT, 3(1), 19-26. https://doi.org/10.36226/jrmb.v3i1.82

Indriyani, M., Nurlaela, S., \& Wahyuningsih, E. M. (2016). Pengaruh Keadilan, Sistem Perpajakan, Diskriminasi dan Kemungkinan Terdeteksinya Kecurangan Terhadap Persepsi Wajib Pajak Orang Pribadi Mengenai Perilaku Tax Evasion. Prosiding Seminar Nasional IENACO, 818-825.

Jensen, M. C., \& Meckling, W. H. (1976). Theory of the firm: Managerial behavior, agency costs and ownership structure. Journal of Financial Economics, 3(4), 305-360. 
Jusman, J., \& Nosita, F. (2020). Pengaruh Corporate Governance, Capital Intensity dan Profitabilitas Terhadap Tax Avoidance pada Sektor Pertambangan. Jurnal Ilmiah Universitas Batanghari Jambi, 20(2), 697. https://doi.org/10.33087/jiubj.v20i2.997

Kurniasih, T., \& Ratna Sari, M. (2013). Pengaruh Return on Assets, Leverage, Corporate Governance, Ukuran Perusahaan Dan Kompensasi Rugi Fiskal Pada Tax Avoidance. Buletin Studi Ekonomi, 18(1), 58-66.

Loderer, C., \& Waelchli, U. (2010). Firm age and performance.

Murphy, K., \& Tyler, T. (2008). Procedural justice and compliance behaviour: The mediating role of emotions. European Journal of Social Psychology, 38(4), 652-668.

Oktamawati, M. (2017). Pengaruh Karakter Eksekutif, Komite Audit, Ukuran Perusahaan, Leverage, Pertumbuhan Penjualan, Dan Profitabilitas Terhadap Tax Avoidance. Jurnal Akuntansi Bisnis, 15(1), 23-40. https://doi.org/10.24167/JAB.V15I1.1349

Oktamawati, M. (2019). Pengaruh karakter eksekutif, komite audit, ukuran perusahaan, leverage, pertumbuhan penjualan, dan profitabilitas terhadap tax avoidance. Jurnal Akuntansi Bisnis, 15(1), 23-40.

Putriningsih, D., Suyono, E., \& Herwiyanti, E. (2018). Profitabilitas, leverage, komposisi dewan komisaris, komite audit, dan kompensasi rugi fiskal terhadap penghindaran pajak pada perusahaan perbankan. Jurnal Bisnis Dan Akuntansi, 20(2), 77-92.

Rosa Dewinta, I., \& Ery Setiawan, P. (2016). Pengaruh Ukuran Perusahaan, Umur Perusahaan, Profitabilitas, Leverage, Dan Pertumbuhan Penjualan Terhadap Tax Avoidance. E-Jurnal Akuntansi Universitas Udayana, 14(3), 1584-1615.

Sinambela, T., \& Naibaho, P. (2019). PENGARUH RETURN ON ASSETS, LEVERAGE DAN UKURAN PERUSAHAAN TERHADAP PENGHINDARAN PAJAK (TAX AVOIDANCE). GOODWILL, 1(1 April), 68-80.

Subagiastra, K., Arizona, I. P. E., \& Mahaputra, I. N. K. A. (2017). Pengaruh profitabilitas, kepemilikan keluarga, dan good corporate governance terhadap penghindaran pajak (Studi pada perusahaan manufaktur di Bursa Efek Indonesia). JIA (Jurnal Ilmiah Akuntansi), 1(2).

Sugiyarti, S. M. P. L. (2017). Pengaruh Intensitas Aset Tetap, Pertumbuhan Penjualan Dan Koneksi Politik Terhadap Tax Avoidance (Studi Kasus Pada Perusahaan Manufaktur Yang Terdaftar Di Bursa Efek Indonesia Tahun 2012-2016). Jurnal Riset Akuntansi Dan Keuangan, 5(3), 1625-1642. https://doi.org/10.17509/jrak.v5i3.9225

Triyanti, N. W., Titisari, K. H., \& Dewi, R. R. (2020). Pengaruh Profitabilitas, Size, Leverage, Komite Audit, Komisaris Independen dan Umur Perusahaan terhadap Tax Avoidance. Jurnal Ilmiah Universitas Batanghari Jambi, 20(1), 113-120.

Widiayani, N. P. A., Sunarsih, N. M., \& Dewi, N. P. S. (2019). Pengaruh Leverage, Umur Perusahaan, Profitabilitas, Dan Pertumbuhan Penjualan Terhadap Tax Avoidance. Kumpulan Hasil Riset Mahasiswa Akuntansi (KHARISMA), 1(1), 183-197. 